\title{
Prožitkové naučné stezky jako prostředek environmentální interpretace krajiny
}

Veronika Beňková, Jan Činčera

Envigogika 2010/V/2- Recenzované články/ Reviewed Papers

Publikováno/Published 30. 09. 2010

DOI: http://dx.doi.org/10.14712/18023061.51

\begin{abstract}
Abstrakt:
Nejrozšiřenějším prostředkem environmentální interpretace jsou v České republice naučné stezky. Kromě tradičního typu stezek zaměřeného na předávání informací o lokalitě textovou či obrazovou formou se v poslední době začínají objevovat také stezky nabízející návštěvníkům různé prožitkově orientované aktivity s cílem posílit jejich motivaci $\mathrm{k}$ učení. Příspěvek prezentuje výsledky smíšeného evaluačního výzkumu porovnávající dvě dvojice "tradičních" a "prožitkových" naučných stezek v Libereckém kraji. Sledované prožitkové stezky byly pro návštěvníky atraktivnější, ale vedly k zapamatování srovnatelného množství znalostí o lokalitě, jako stezky tradiční.
\end{abstract}

\section{Klíčová slova:}

Naučné stezky, evaluační výzkum, environmentální interpretace

\section{Abstract:}

The most popular means for environmental interpretation in the Czech Republic are learning trails. Other than the common type of trails focusing on transmitting information about a place in a written or picture format, a new form of trail offering participants various experiential activities with the aim of motivating them to learn has begun to appear. The paper presents the results of a mixed evaluation comparing two pairs of "traditional" and "experiential " learning trails in the Liberec region. The monitored experiential trails were more attractive for visitors, but the amount of knowledge retained about the locality was comparable to the traditional trails.

\section{Key words:}

Learning trails, evaluation research, environmental interpretation 


\section{Úvod}

Environmentální interpretace, př́padně interpretace přírodního a kulturního dědictví, jsou $v$ České republice poměrně málo používané pojmy. Obsah environmentální interpretace je u nás zpravidla zařazován do kontextu environmentální výchovy, respektive environmentální výchovy, vzdělávání a osvěty. $V$ anglofonní literatuře jde ale o dvě blízké, nicméně odlišné oblasti výchovně vzdělávacího pưsobení.

Podle Evansové (2004) je environmentální interpretace „...proces komunikace, jehož účelem je pomoci odhalovat významy a vztahy našeho kulturního a přirodního dédictví, a to prostřednictvím zapojení předmětů, artefaktů, krajiny a pamětihodností". Environmentální interpretace je tak na rozdíl od environmentální výchovy pevně spjatá s konkrétní lokalitou, kterou učí návštěvníky interpretovat a při tom formuje jejich postoje a chování. Prostřednictvím uplatňovaných programů pomáhá návštěvníkủm porozumět místu, odkrývat jej z různých rovin a nacházet $v$ něm smysl. Dobře připravené programy dokážou návštěvníky zaujmout, motivovat i strhnout k emocím (Beck \& Cabel, 2002; Ham, 1992).

Knapp (1997) upozorňuje na několik základních rozdílů mezi oběma disciplínami. Environmentální výchova je podle něj typicky spojovaná s formálními institucemi a předpokládá určitý dlouhodobější proces. Naopak environmentální interpretace je ryze dobrovolnou a krátkodobou činností. Ve srovnání senvironmentální výchovou má environmentální interpretace méně propracovanou teorii a je $v$ mnohem menší míře výzkumně zmapována.

Na druhé straně sdílejí obě disciplíny stejné hlavní cíle. V roce 1997 definovali Knapp, Volková a Hungerford (1997) cíle environmentální interpretace v kontextu modelu odpovědného environmentálního chování (Hungerford \& Volková, 1990). Podle nich je hlavním cílem interpretace odpovědné chování návštěvníka dané lokality. Cestou ke změně chování pak je naplnění vstupních cílů (informace o místu, porozumění jeho potřebám, senzitivita), vlastnických cílů (porozumění místním zdrojům a problémům) a participačních cílů (odpovědnost a související akční kompetence).

Ve srovnání s environmentální výchovou byly programy environmentální interpretace dosud jen zřídka vyhodnocovány. Jeden z mála evaluačních výzkumů prezentuje Knapp (1996). Knapp porovnává efektivitu tř́ programů, které realizovalo oddělení Rekreace a administrativy parků University of Indiana. Programů se zúčastnilo přes 2000 studentů, žáků a učitelů ze základních a středních škol. Každý program měl dvě verze. První nabízela ekologické zaměření s př́mou exkurzí do přírody, druhou byl program se zaměřením na řešení vybraných problémů lokality bez exkurze do terénu. Výsledky z lokality Indiana Dunes National Lakeshore jasně ukázaly, že nejefektivnějším programem ovlivňující postoje a chování studentů, je program ekologicky laděný, který je doplněn terénní exkurzí. Program, který vyžadoval od studentů návrhy na řešení problémů bez exkurze do terénu, neměl na postoje a změnu chování studenta statisticky významný vliv.

$\checkmark$ České republice jsou nejpoužívanějším prostředkem environmentální interpretace naučné stezky. Naučnou stezku definuje Kocián (2003) jako: „převážně pěší turistická značená trasa, která má za cíl návštěvníkovi sdělit zajímavé informace o prírodovědných, vlastivědných, popř. historických aspektech dané lokality nebo oblasti, již prochází. Cílem naučných stezek je vzdělávání široké veřejnosti. Většina naučných stezek vzniká $v$ př́rodně bohatých a zachovalých lokalitách s cílem pưsobit výchovně na návštěvníky a ukázat bohatství prírody, které je potřeba chránit."

Tvorba naučných stezek má velkou podporu ve Spojených státech amerických a $\vee$ Kanadě, kde se také začaly používat. Evaluace vybraných interpretačních naučných stezek dokázala, že naučné stezky zvyšují atraktivitu lokality a navíc pozitivně působí na 
kognitivní a afektivní stránku návštěvníka (Warner, 2009). Pro tvorbu jednotlivých informačních cedulí či celých naučných stezek, dle principů environmentální interpretace, jsou k dispozici na internetu či v literatuře konkrétní rady a návody.

Podle Kočí a Mrázové (2009) by stezky měly být atraktivní a informativní, měly by šetrně a esteticky splynout s okolím, měly by být odolné proti povětrnostním vlivům a vandalům, a měly by upřednostňovat ekologicky šetrné materiály. Klíčem k úspěchu je výběr vhodné lokality a interpretačního tématu, následně rozpracovaného do dílčích podtémat př́běhovou linkou. Dobře fungující stezka by měla mít jasně vymezené interpretační cíle vycházející z analýzy trhu - návštěvníků stezky. Efektivita stezek by měla být průběžně evaluována. Stezky by měly využívat prostředky aktivního učení a pracovat s prožitkovými aktivitami.

Přestože většina naučných stezek je založena na předávání informací o lokalitě formou textu a obrázků, začínají se u nás v posledních letech po vzoru okolních zemí i stezky zapojující návštěvníky do rưzných prožitkově orientovaných aktivit. Návštěvníci tak mohou na stanovišti např́klad hrát poznávací hry, zapojovat se do aktivit zaměřených na smyslový kontakt s přírodou či řešit různé hádanky (Amann, 2003). Lze předpokládat, že tyto "prožitkově" orientované naučné stezky budou atraktivnější, zaujmou širší segment návštěvníků a napomůžou k efektivnějšímu učení. ověřit.

Cílem prezentovaného evaluačního výzkumu bylo tento předpoklad na malém vzorku

\section{Metodika výzkumu}

Prezentovaný výzkum porovnává efektivitu dvou párů tradičních a prožitkových naučných stezek v Libereckém kraji. Prožitková naučná stezka je zde chápána jako stezka, která kromě poskytovaných informací požaduje interakci a zapojuje návštěvníky do prožitkově orientovaných aktivit. Oproti tomu tradiční naučné stezky jsou zde chápány jako stezky obsahující pouze informace o dané lokalitě a nenabízející návštěvníkům žádnou doplňující aktivitu.

V rámci výzkumu byly řešeny následující otázky:

1. Tráví návštěvníci u stanovišt vybraných prožitkových naučných stezek více času než u zastávek srovnatelných tradičních naučných stezek?

2. Pamatují si návštěvníci více poznatků z tradičních nebo z prožitkových naučných stezek?

Obě otázky byly řešeny metodou komparativních případových studií. Na základě vstupní analýzy naučných stezek v Libereckém kraji byly vybrány dvě dvojice stezek se srovnatelnými parametry, kdy jedna byla vždy klasifikována jako prožitková a druhá jako tradiční. Šlo tedy o využití metody smysluplného vzorkování na základě daného kritéria (Patton, 2002). Přestože jádrem analýzy je kvalitativní komparace, byly pro větší výpovědní hodnotu využity i statistické postupy. Analýza má tedy jako celek smíšený charakter typu QUAL+quan (Hendl, 2008, s. 279). Tento typ výzkumu je typický zejména pro evaluační výzkumy, kterým tato část práce svým charakterem odpovídá.

Vzhledem k tomu, že vzorek nebyl vybrán metodou náhodného výběru, nelze jeho výsledky zobecňovat za účelem získání výpovědi o všech tradičních, resp. prožitkových naučných stezkách. Vzhledem k rưznorodosti naučných stezek v obou kategoriích lze také pochybovat, zda by byla taková generalizace vůbec smysluplná (není možné efektivně kontrolovat všechny intervenující proměnné - terén, téma stezky, estetické provedení atd).

Data byla sbírána od června 2009 do dubna 2010. Prvním krokem bylo navštívení všech naučných stezek Libereckého kraje. V Libereckém kraji v tomto období bylo prístupno celkem 32 naučných stezek, z toho pět bylo hodnoceno jako "prožitkových": 
Oldřichovské háje a skály, Lesní naučná stezka Sedmihorky, Harcov, Hravé putování Ještědským lesem a Putování skřítka Javoříčka.

Následně byly vybrány dvě dvojice naučných a prožitkových stezek. Protože stezky jsou natolik různorodé, že z nich nelze vytvořit páry vylučující vliv intervenujících proměnných, byly vybrány stezky $v$ alespoň přibližně podobných lokalitách a se srovnatelnou návštěvností. Pro výzkum byly vybrány následující dvojice prožitkových a tradičních stezek:

- Jizerka (tradiční) - Oldřichovské háje a skály (prožitková)

- Jedlový důl (tradiční) - Lesní naučná stezka Sedmihorky (prožitková).

U každé stezky bylo pro sběr dat vybráno jedno stanoviště. Data byla získávána za srovnatelných povětrnostních podmínek a teploty a ve stejný den v týdnu (sobota).

V rámci výzkumu bylo nejprve každé stanoviště popsáno a analyzováno z hlediska estetického dojmu, udržovanosti a poměru textové a obrazové části. Následně byly monitorovány tyto údaje:

- Identifikační údaje respondentů, zahrnující jejich pohlaví, věk a dosažený stupeň vzdělání

- Podíl mezi návštěvníky, kteří se zastavili u sledovaného stanoviště z celkového počtu procházejících návštěvníků.

- Doba strávená čtením a aktivitami u stanoviště.

- Znalosti odpovídající dosavadním zastavením naučné stezky zjištěné jednoduchým následným testem (posttestem).

Kvantitativní data byla následně v rámci sledovaného páru porovnávána pomocí statistických metod. Vědomostní test byl vytvořen tak, aby odrážel znalosti prezentované na stanovištích stezky a současně aby otázky na obou porovnávaných stezkách byly srovnatelné co do obsahu i náročnosti (viz příloha).

V analýze atraktivity stezky (podíl návštěvníků, kteří se zastavili na stanovišti a doba strávená na stanovišti) nebyli návštěvníci, kteří přišli ve skupině, hodnoceni jako jednotlivci, ale jako vícečlenné "jednotky". Důvodem byl předpoklad, že individuální rozhodování jednotlivce bývá podstatně ovlivněno skupinou. Vědomostní testy byly naopak vyplňovány pouze jednotlivci.

Pro analýzu kvantitativních dat byly využity čtyři statistické metody. Statistická významnost rozdílu $v$ četnostech byla vyhodnocena pomocí kontingenční tabulky $\left(x^{2}\right)$. Protože délka zastavení návštěvníka u sledované tabule byla měřena $v$ sekundách, bylo možné tato data chápat jako parametrická a použít nepárový t-test. Bodové výsledky z testů jsme porovnávali pomocí Wilcoxonova nepárového testu určeného pro ordinální data. Protože v korelační analýze byly vyhodnocovány souvislosti mezi parametrickými a ordinálními daty, zvolili jsme Spearmanův test, který je pro ordinální data vhodný. Hladina významnosti byla pro všechny testy stanovena na a=0,05 (Hendl, 2004).

\section{Prezentace výsledků}

\section{Naučná stezka Jizerka}

Naučná stezka Jizerka představuje tradiční typ stezky. Nachází se v osadě Jizerka a patří mezi nejstarší vybudované naučné stezky v CHKO Jizerské hory. Je součástí mezinárodní stezky Tři Iseríny a obsahuje patnáct tabulí. Na šesti kilometrech má celkem 
patnáct zastavení. Prochází přírodní rezervací Bukovec, starou zlatokopeckou, sklářskou a dřevorubeckou osadou Jizerkou a pokračuje územím NPR Rašeliniště Jizerky. Od této trasy se odvíjejí i témata jednotlivých zastavení, na kterých se návštěvníci mohou seznámit s geologickými, botanickými i zoologickými zajímavostmi území, s historií horské osady i některými činnostmi, kterým se $v$ historických dobách místní obyvatelé věnovali. Vedle turistů a návštěvníkư přijiždějících do Jizerských hor individuálně stezka slouží rovněž jako terénní výuková trasa pro školy $v$ přírodě, studenty i učitele a další subjekty, zejména v rámci výukových programů nově otevřeného Střediska ekologické výchovy na Jizerce provozovaného Společností pro Jizerské hory, o.p.s.

Z naučné stezky Jizerka byl pro zkoumání míry atraktivity vybrán panel číslo 7 s názvem Úpolínová louka. Panel se vyskytuje pod Bukovcem na místě, kde je výhled na Úpolínovou louku a osadu Jizerku. K odpočinku jsou k dispozici dřevěné lavice a stůl. Tento panel seznamuje návštěvníka s rostlinou úpolín, která se stala symbolem CHKO Jizerské hory, dále s historií místa a vysvětlením pojmu ptáčnictví, který se k této lokalitě vztahuje. Text tabule je dvoujazyčný, česko-polský, a doplněný ilustracemi jednotlivých druhů ptactva, které se zde vyskytují a které dřive čihaři lovili. Na panelu je název stanoviště, číslo zastavení, znak CHKO Jizerských hor a loga sponzorů.

Trasa naučné stezky vede poměrně náročným terénem. Panely jsou vsazeny do dřevěných stojanů, aby esteticky nenarušovaly okolí. Samotný text a grafika jsou chráněny plexisklem, které pưsobí v rázu krajiny nevhodně, ale odolává povětrnostním podmínkám. Kombinace obou materiálů prodlužuje celkovou životnost naučné stezky. Jednotlivé panely obsahují možná až přespř́liš textu strohého, výkladového charakteru. Text je doplněn tematickými fotografiemi či obrázky. Každý panel má své pořadové číslo a obsahuje loga sponzorů a zřizovatelư. Jednotlivé panely pưsobí na první pohled všechny stejně a poněkud fádně, postrádají interaktivní prvky. Celkový stav stezky je ale velmi dobrý. Stezka působí upraveně, čistě a př́ijemně. Panely nenesou žádné stopy poničení.

Panel č. 7 je esteticky zasazen do prrírody a v kombinaci s vedle stojícím dřevěným stolem a lavicemi tvoří př́ijemné odpočívadlo. Text panelu č. 7 je napsán bíle na zeleném podkladu. Písmo je čitelné a forma prezentování informací celkem srozumitelná a pochopitelná, možná více určena odborné veřejnosti. Na první pohled pưsobí text trochu stroze, nahuštěně, fádně a obsahuje možná až přespřiliš detailních informací. Latinské názvy popisovaného ptactva ocení pouze úzký okruh návštěvníků. Čtenáři tak mưže na úkor konkrétních věcí unikat celková podstata. Celkově působí tabule ale systematicky a návštěvník letmým pohledem zjistí obsah panelu.

Sběr dat proběhl u sledovaného panelu ve dnech 20. června 2009 a 7. listopadu 2009. Oba dny byly slunečné a jasné. V červnu byla teplota $v$ den pozorování $20^{\circ} \mathrm{C}$ a v listopadu se pohybovala kolem $0^{\circ} \mathrm{C}$. Celkově prošlo stanovištěm 36 jednotek. Z 36 jednotek se u panelu zastavilo 27 jednotek. Průměrně strávila jedna jednotka u panelu 3,28 minut.

Tabulka 1: Průměrný čas strávený jednotkami u panelu č. 7 NS Jizerka

\begin{tabular}{|l|l|l|l|l|}
\hline Jizerka & $\begin{array}{l}\text { Celkem } \\
\text { prošlo }\end{array}$ & $\begin{array}{l}\text { Celkem } \\
\text { zastavilo }\end{array}$ & $\begin{array}{l}\text { Podíl prošli - navštívili } \\
(\%)\end{array}$ & $\begin{array}{l}\text { Průměrná délka } \\
\text { zastavení (minuty) }\end{array}$ \\
\hline Panel č.7 & 36 & 27 & 75 & 3,28 \\
\hline
\end{tabular}


Tabulka 2: Počet osob zaznamenaných u panelu č.7 NS Jizerka

\begin{tabular}{|l|l|l|l|l|}
\hline $\begin{array}{l}\text { Jizerka } \\
\text { Panel č.7 }\end{array}$ & Počet osob & Počet žen & Počet mužů & Nezastavilo osob \\
\hline 20.6 .2009 & 94 & 27 & 56 & 11 \\
\hline 7.11 .2009 & 84 & 36 & 39 & 9 \\
\hline
\end{tabular}

Vliv naučné stezky na znalosti byl měřen pomocí znalostního testu. Respondenty tvořilo 27 mužů a 23 žen. Z testu bylo možné získat nejvíce devět bodů.

Tabulka 3: Průměrný bodový zisk respondentů a přehled zkoumaných vlastností respondentů NS Jizerka

\begin{tabular}{|l|l|l|l|l|l|l|l|l|l|}
\hline Jizerka & $\begin{array}{l}\text { Počet } \\
\text { osob }\end{array}$ & Muži & $\begin{array}{l}\text { Ženy } \\
\text { bodơnérný } \\
\text { zisk } \\
\text { stezky }\end{array}$ & $\begin{array}{l}\text { Průměr } \\
\text { muži }\end{array}$ & $\begin{array}{l}\text { Průměr } \\
\text { ženy }\end{array}$ & $\begin{array}{l}\text { Počet } \\
\text { VŠ }\end{array}$ & $\begin{array}{l}\text { Průměrný } \\
\text { bodový } \\
\text { zisk VŚ }\end{array}$ & $\begin{array}{l}\text { Průměrný věk } \\
\text { respondentů }\end{array}$ \\
\hline 50 & 27 & 23 & 4,82 & 4,62 & 5,04 & 9 & 6,14 & 30,28 \\
\hline
\end{tabular}

$M=$ průměr (bodový zisk ze znalostních dotazníků, věk, čas), vŠ= vysoká škola (absolventi)

\section{Naučná stezka Jedlový důl}

Naučná stezka Jedlový důl patří mezi tradiční typy stezek. Leží v CHKO Jizerské hory a prochází př́rodní rezervací Jedlový důl. Cesta z Liberce trvá k naučné stezce 45 minut jízdy automobilem. Trasa naučné stezky je dlouhá 3,5 km a prochází členitým terénem podél řeky Jedlová. Stezka je určena pouze pěším. Obsahuje celkem šest panelů, které seznamují s přírodními hodnotami rezervace, jako jsou zbytky původních přirozených jedlo-bukových porostů s významnými rostlinnými a živočišnými druhy, skalními útvary a vodopády. Pro usměrnění pohybu návštěvníků, bezpečnosti a ochraně prostředí vedou na určitých místech turistické povaly. Stezku připravila a realizovala ve spolupráci s Nadací pro záchranu a obnovu Jizerských hor a Správu CHKO Jizerské hory Společnost pro Jizerské hory o.p.s. v roce 2000.

Pro zkoumání míry atraktivity naučné stezky Jedlový důl byl vybrán panel č. 6. Panel se nachází na odpočívadle Vodopády Jedlové a jmenuje se Rostliny a živočichové $v$ lese. Obsahem panelu jsou lesní porosty na území prírodní rezervace, bylinné patro a hnízdící ptactvo. Tabule obsahuje obrázky vzácně se vyskytujícího ptactva, znak CHKO Jizerských hor a loga sponzorů.

Trasa naučné stezky vede členitým terénem a předpokládá střední fyzickou zdatnost. Návštěvník prochází po určené cestě pưvodním lesem a překonává rưzné kamenité nerovnosti. Jednotlivé panely se nacházejí přímo u cesty, takže je pěší turista nepřehlédne. Jsou tvořeny dřevěným rámem a zelenou plastovou cedulí, na které je napsán bílou barvou text. Z hlediska estetiky a zasazení do krajiny panely svým vzhledem nenarušují ráz lokality, místy dokonce splývají s přírodou. Panely jsou umístěny na stanovištích, na kterých se nachází předmět či jev, se kterým má být návštěvník obeznámen. Problémem některých panelů je ale jejich nevhodné umístění. Většině panelů chybí dostatečný okolní prostor, Některé panely jsou navíc vyřešeny nevhodným 
způsobem. Text tabule č. 5 je umístěn příliš vysoko, až nad úrovní očí, což je pro návštěvníka nepohodlné. Text na tabulích je strohý, krátký a věcný, a je doplněn obrázky. U vybraných druhů živočichů a rostlinstva se vyskytují spolu s českými názvy i latinské. Celkově působí stezka decentně a nenuceně, ale zároveň i trochu zanedbaně a neupraveně. Některé tabule nesou navíc známky poškození a vandalismu. Návštěvník lehce rozpozná rozdíl mezi pưvodními a novými stanovišti, jako např. U Černé tůně, kde se nově nachází panel a odpočívadlo s dřeveným stolem a lavicemi.

Panel č. 6, který zkoumá atraktivitu naučné stezky, se nachází na zajímavém místě zvaném Vodopády Jedlové. Stanoviště nabízí krásný výhled na vodopády a posezení na velkých balvanech, na kterých si návštěvník může odpočinout. Místo je zabezpečeno novým zábradlím. Panel by ale mohl stát spíše směrem $\mathrm{k}$ vodopádům $\mathrm{z}$ pohledu návštěvníka, místo toho je postaven u cesty, směrem do svahu. Návštěvníci čtou informace z panelu č. 6, zatímco vodopády a les mají za zády. Takové řešení je nevhodné už proto, že se návštěvník při čtení a pozorování musí otáčet mezi tabulí a popisovaným jevem. Co se týče textu informační tabule, je srozumitelný, krátký, ale poněkud fádní. Neobsahuje atraktivní prvky. Návštěvníka mohou přilákat k panelu pouze obrázky zdejších hnízdících ptáků.

Sběr dat proběhl na panelu č. 6 ve dnech $27.6 .$, kdy bylo polojasné počasí a $24^{\circ} \mathrm{C}$, a 21. 11. 2009, kdy bylo jasno a teplota kolem $0^{\circ} \mathrm{C}$.

Tabulka 4: Průměrný čas strávený jednotkami u panelu č. 6 NS Jedlový důl

\begin{tabular}{|l|l|l|l||l|}
\hline $\begin{array}{l}\text { Jedlový důl } \\
\text { Panel č. } 6\end{array}$ & $\begin{array}{l}\text { Celkem } \\
\text { prošlo }\end{array}$ & $\begin{array}{l}\text { Celkem } \\
\text { zastavilo }\end{array}$ & $\begin{array}{l}\text { Podíl prošli- navštívili } \\
(\%)\end{array}$ & $\begin{array}{l}\text { Průměrná délka } \\
\text { zastavení (minuty) }\end{array}$ \\
\hline & 49 & 41 & 84 & 2,25 \\
\hline
\end{tabular}

Tabulka 5: Počet osob zaznamenaných u panelu č.6 NS Jedlový důl

\begin{tabular}{|l|l|l|l|l|}
\hline $\begin{array}{l}\text { Jedlový důl } \\
\text { Panel č. } 6\end{array}$ & Počet osob & Počet žen & Počet mužů & Nezastavilo osob \\
\hline 27. 6. 2009 & 108 & 36 & 62 & 10 \\
\hline 21.11 .2009 & 112 & 35 & 71 & 6 \\
\hline
\end{tabular}

Pro hodnocení zapamatovaných vědomostí bylo vybráno celkem padesát dotazníků, z toho 31 respondentů tvořily ženy, 19 muži. Průměrně získali respondent 5,54 z devíti možných bodů.

Tabulka 6: Průměrný bodový zisk respondentů a přehled zkoumaných vlastností respondentů NS Jedlový důl

\begin{tabular}{|l|l|l|l|l|l|l|l|l|l|}
\hline $\begin{array}{l}\text { Jedlový } \\
\text { důl }\end{array}$ & $\begin{array}{l}\text { Počet } \\
\text { osob }\end{array}$ & Muži & Ženy & $\begin{array}{l}\text { Průměrný } \\
\text { bodový zisk } \\
\text { stezky }\end{array}$ & $\begin{array}{l}\text { Průměr } \\
\text { muži }\end{array}$ & $\begin{array}{l}\text { Průměr } \\
\text { ženy }\end{array}$ & $\begin{array}{l}\text { Počet } \\
\text { VŠ }\end{array}$ & $\begin{array}{l}\text { Průměrný } \\
\text { bodový zisk } \\
\text { VŠ }\end{array}$ & $\begin{array}{l}\text { Průměrný věk } \\
\text { respondentů }\end{array}$ \\
\hline & 50 & 19 & 31 & 6 & 5,94 & 6,03 & 12 & 7,6 & 31,18 \\
\hline
\end{tabular}




\section{Naučná stezka Oldřichovské háje a skály}

Prožitková stezka Oldřichovské háje je situovaná nad Oldřichovem v Hájích v CHKO Jizerské hory. Z vlakové stanice trvá cesta k začátku trasy naučné stezky cca 20 minut. Naučná stezka Oldřichovské háje a skály je specifická tím, že obsahuje dvě trasy zároveň. Delší trasa $(10 \mathrm{~km})$ je určená běžným návštěvníkům a poskytuje jim na patnácti tabulích informace tradičním způsobem. Kratší trasa je převážně zřízena pro mladší a školní věk a je pojata jako prožitková. Pro zajištění dvou variant stezky je prvních osm panelů oboustranných. Z jedné strany je zpracována tématika Oldřichovských hájů tradičním způsobem, druhá strana je vytvořena prožitkově. Pro dospělé návštěvníky jsou určeny naučné cedule Správy CHKO Jizerské hory. Tato stezka vede ze sedla souběžně se stezkou pro děti až k Hřebenovému buku, tam se od ní odpojuje a pokračuje dále zajímavou trasou okolo Špičáku.

Kratší (prožitková) trasa naučné stezky Oldřichovské háje a skály začíná v Oldřichovském sedle (Hemrich) a pokračuje přes Kopřivník a Lysé skály ke Skalnímu hradu a odtud dále k Hřebenovému buku a zpět do Oldřichova. Délka trasy je $5 \mathrm{~km}$. Zastavení tvoří 10 tabulí, které návštěvníka seznamují s místní geologií, geomorfologií, lesním ekosystém, květenou, zástupci živočišné říše a osídlením Jizerských hor. Každý panel obsahuje své číslo, orientační mapku s vyznačeným okruhem a místem, kde se právě návštěvník nachází. $V$ mapce je zároveň počítadlo, které popisuje, kolik kilometrů návštěvník ušel a kolik jich ještě do konce trasy zbývá. Na každém panelu je znak společnosti Suchopýr o.p.s. Původní naučnou stezku vybudoval v roce 1986 Český svaz ochráncủ přírody. Současná podoba stezky vznikla v roce 2003, kdy byla i slavnostně otevřena jako výsledek spolupráce mezi Správou CHKO Jizerské hory, ČSOP a o.p.s. Trasa je určená pouze pro pěší. Nachází se zde řada schodů a žebříků na skalní vyhlídky a z toho důvodu je naprosto nevhodná pro cyklisty. Pro pěší platí v národní prírodní rezervaci zákaz vstupu mimo vyznačenou trasou pod hrozbou pokuty. Naučná stezka je součástí výukových programů pro školy Střediska ekologické výchovy Libereckého kraje.

Pro měření atraktivity na prožitkové stezce Oldřichovské háje a skály byl vybrán panel č. $7 \mathrm{~s}$ názvem Role člověka $v$ prrírodě. Panel se nachází na Hřebenovém buku, kde je stanoviště s odpočívadlem ve formě dřevěného altánu. Vedle panelu stojí interaktivní stůl, kde je úkolem návštěvníka dobře přiřadit tvar větve ke správnému druhu stromu. Hříbek Bukovník seznamuje na tomto panelu návštěvníka s původní i současnou skladbou lesů.

Stezka vyžaduje větší fyzickou zdatnost. Prochází členitým terénem bučinových lesů a skalních útvarů. Jednotlivé panely jsou vyrobeny ze dřeva a z plastu. Text informačních tabulí je srozumitelný, čitelný a je propojen velkým množstvím obrázků a př́kladů. Celou naučnou stezkou provází postavička hříbka Bukovníka, kterým dětem poskytuje na tabulích rady, tipy, úkoly, hry a kvízy. Tato prožitková naučná stezka vyžaduje od návštěvníka interakci a zaměřuje se na všechny jeho poznávací smysly. Součástí stezky jsou stanoviště, kde se nachází dřevěné stoly, na kterých si děti zařazováním dřevěných kostek doplní a osvěží své znalosti o stromech a obyvatelích lesa. Panely nenarušují charakter oblasti a jsou umístěny na atraktivních a bezpečných místech. Mají kolem sebe dostatek místa a díky dřevu a pastelovým barvám působí přirozeně a př́jemně. Stezka seznamuje hravou formou s vývojem lesa, životem i osídlením zejména západní části Jizerských hor. Celkově působí naučná stezka hravě, rozmanitě, příjemně a zábavně. Stezka je ve velmi dobrém stavu. Je upravená, žebříky a chodníky jsou bezpečné a panely nepoškozené.

Stanoviště č. 7 se nalézá na př́jemném prostorném místě. Je přehledné, vzdálené pár metrů od altánku a celkově působí atraktivně. Návštěvník si může $v$ klidu přečíst panel a posléze manipulovat $s$ interaktivním stolem. Téma tabule je zpracováno formou přiřazování vět k obrázku. Správnost tvrzení si může čtenář sám ověřit pomocí řešení, které je napsáno na panelu menším písmem vzhưru nohama. Text je čitelný, černý na béžovém podkladě, srozumitelný, pochopitelný a díky úkolu také zapamatovatelný. Stanoviště je upravené a plně funkční. Sběr dat proběhl ve dnech 13.6. , kdy bylo 
polojasno, $23^{\circ} \mathrm{C}$, a 31.10 . 2009. kdy bylo jasno, ale větrno a teplota kolem $0^{\circ} \mathrm{C}$. Dohromady prošlo kolem vybraného panelu 41 kolemjdoucích, z toho 9 se jich nezastavilo. Průměrný čas strávený u panelu byl 4,93 minut.

Tabulka 7: Průměrný čas strávený jednotkami u panelu č.7 NS Oldřichovské háje a skály

\begin{tabular}{|l|l|l|l|l|}
\hline $\begin{array}{l}\text { Oldřichov } \\
\text { Panel č. 7 }\end{array}$ & $\begin{array}{l}\text { Celkem } \\
\text { prošlo }\end{array}$ & $\begin{array}{l}\text { Celkem } \\
\text { zastavilo }\end{array}$ & $\begin{array}{l}\text { Podíl prošli- navštívili } \\
(\%)\end{array}$ & $\begin{array}{l}\text { Průměrná délka } \\
\text { zastavení (minuty) }\end{array}$ \\
\hline & 41 & 32 & 78 & 4,93 \\
\hline
\end{tabular}

Tabulka 8: Počet osob zaznamenaných u panelu č. 7 NS Oldřichovské háje a skály

\begin{tabular}{|l|l|l|l|l|}
\hline $\begin{array}{l}\text { Oldřichov } \\
\text { Panel č. } 7\end{array}$ & Počet osob & Ženy & Muži & $\begin{array}{l}\text { Nezastavilo } \\
\text { osob }\end{array}$ \\
\hline 13. 6.2009 & 100 & 40 & 50 & 10 \\
\hline 31.10 .2009 & 95 & 39 & 43 & 13 \\
\hline
\end{tabular}

Vliv stezky na znalosti o místě byl vyhodnocen pomocí testů. Průměrný bodový zisk jednoho návštěvníka byl 5,62 z osmi možných. Průměrný věk respondentů byl 27,66 let. Z celkového počtu 50 respondentů, jich 7 má vysokoškolský titul.

Tabulka 9: Průměrný bodový zisk respondentů a přehled zkoumaných vlastností respondentů NS Oldřichovské háje a skály

\begin{tabular}{|l|l|l|l|l|l|l|l|l|l|}
\hline $\begin{array}{l}\text { Oldřichovské } \\
\text { háje a skály }\end{array}$ & $\begin{array}{l}\text { Počet } \\
\text { osob }\end{array}$ & Muži & $\begin{array}{l}\text { Ženy } \\
\text { Průměrný } \\
\text { bodový } \\
\text { zisk } \\
\text { stezky }\end{array}$ & $\begin{array}{l}\text { Průměr } \\
\text { muži }\end{array}$ & $\begin{array}{l}\text { Průměr } \\
\text { ženy }\end{array}$ & $\begin{array}{l}\text { Počet } \\
\text { VŠ }\end{array}$ & $\begin{array}{l}\text { Průměrný } \\
\text { bodový } \\
\text { zisk VŚ }\end{array}$ & $\begin{array}{l}\text { Průměrný } \\
\text { věk } \\
\text { respondentů }\end{array}$ \\
\hline & 50 & 23 & 27 & 5,46 & 5,22 & 5,66 & 7 & 6,85 & 27,66 \\
\hline
\end{tabular}

\section{Lesní naučná stezka Sedmihorky}

Naučná stezka Sedmihorky se nachází v CHKO Český ráj. Začíná a končí v kempu Sedmihorky, kde se přímo nachází centrum ekologické výchovy. Stezka je prožitkového typu s velkým množstvím interaktivních prvků. Z Liberce trvá cesta do Sedmihorek cca 35 minut.

Okružní trasa vede po turisticky značených cestách, lesních cestách a místních komunikacích okolím kempu Sedmihorky, podél přírodních rezervací Bažantník a Hruboskalsko. Doporučeným výchozím bodem je kemp Sedmihorky. Trasa je tříkilometrovým okruhem s celkem sedmnácti zastaveními. Naučná stezka seznamuje návštěvníky s ekosystémem lesa a s charakteristikou lesů CHKO Český ráj. Stezka byla otevřena v roce 2005 a je určena široké veřejnosti. Zároveň slouží jako prostředek výukových programů Střediska ekologické výchovy Český ráj. K trase byl vydán dětský průvodce naučnou stezkou, do kterého si děti píší a kreslí, co cestou viděly a dělaly. Zakoupit průvodce je možné $v$ recepci kempu Sedmihorky, v některých informačních centrech, případně v budově Správy CHKO Český ráj. Tato naučná stezka je určena 
zejména pro dětské návštěvníky. Na každém zastavení je pro ně připraven úkol či hádanka. Děti si zde mohou např́klad zahrát na dřevěný xylofon, obkreslit si listy stromů, zahrát si na zvírátka a další. Hravou formou tak děti i jejich rodiče získají základní informace nejen o lese v Českém ráji. Stezka je přístupná po celý rok.

Pro měření atraktivity Lesní naučné stezky Sedmihorky byl vybrán panel č. 7. Panel se nachází na bezpečném př́jemném stanovišti u rybníka, který seznamuje návštěvníka s typickými druhy stromů zdejšího lesa. Na panelu jsou vyobrazeny obrysy tři druhů stromů. Návštěvník se je snaží svým pohledem na les nad rybníkem najít a pomocí svých znalostí identifikovat. Správnost a doplňující informace nalezne návštěvník odkrytím panelu.

Stezka je fyzicky nenáročná, část trasy je vhodná také pro handicapované osoby. Všechny panely jsou vyrobené ze dřeva, na některých je text vypálen přímo do dřevěných stojanů nebo je $v$ kombinaci s plexisklem. Celodřevěné panely esteticky doplňují zdejší přírodu a působí přirozeně. Lesní naučná stezka je určena především mladšímu školnímu věku, a proto jsou i panely ergonomicky přizpůsobeny dětem. Některé části panelů jsou v kombinaci s plexisklem. Jsou umístěny strategicky na specifických místech, které konkrétně a názorně seznamují návštěvníka s ekosystémem lesa. Panely mají kolem sebe dostatečný prostor, jsou různého tvaru, což zvyšuje atraktivitu stezky, a obsahují minimum textu. Dưraz není primárně kladen na předávání informací, ale na interaktivitu. Většina panelů používá princip odkrývání informací, což znamená, že na panelu je položena otázka, k jejímuž vyřešení slouží indicie ve formě obrázku a k ověření správnosti odpovědi je třeba např. zvednout desku, pod kterou je napsané či vyobrazené řešení. Stezka působí hravě, atraktivně a zaujme jak dětského, tak dospělého návštěvníka. Každý panel má pro orientaci návštěvníka své číslo zastavení. Číslování je bohužel místy nejednoznačné, např. po č. 5 pokračuje rovnou č. 8, a návštěvník, pokud nemá mapku s jednotlivými zastaveními, musí navazující panely hledat. Stezku spravuje ekologické středisko Sedmihorky, ZO ČSOP. Stezka se nachází v hojně navštěvované oblasti a riziko opotřebování a poničení stezky je vysoké. I když stezka jako celek působí atraktivně, některé panely nesou známky poškození a poničení a potřebovaly by opravit.

Panel č. 7 přiláká pozornost návštěvníka svým umístěním u rybníka. Panel je vyroben ze dřeva, na kterém je připevněná deska z plexiskla. Průhledné plexisklo s černým textem tolik nenarušuje přírodní charakter panelu. Text u sedmého zastavení stezky č. 4 je čitelný a pochopitelný. Obsah panelu tvoři otázka s úkolem a vyobrazení obrysů hledaných stromů. Návštěvník si po přečtení otázky chce najít odpověd'. Zde platí pořekadlo "Méně je někdy více". Zároveň je zde uplatněn princip odkrývání informací. Návštěvník si může zkontrolovat svou odpověd' podle řešení, které se ukrývá pod deskou. Stanoviště pưsobí jako celek příjemně, čistě, přirozeně a zajímavě. Nejsou zde přítomny žádné rušivé vlivy.

Data byla sbírána v pozorovacích dnech 6. 6. a 14. 11. 2009 na panelu č. 7. Šestého června bylo slunečno s teplotou $25^{\circ} \mathrm{C}, 14.11$. bylo polojasno s teplotou kolem $8^{\circ} \mathrm{C}$. Během obou pozorování prošlo kolem panelu 55 jednotek, z toho 5 jednotek prošlo bez zastavení. Průměrný čas strávený jednotkou u panelu č. 7 Lesní naučné stezky Sedmihorky byla 4,29 minuty.

Tabulka 10: Průměrný čas strávený jednotkami u panelu č. 7 NS Sedmihorky

\begin{tabular}{|l|l|l|l|l|}
\hline $\begin{array}{l}\text { Sedmihorky } \\
\text { Panel č. 7 }\end{array}$ & $\begin{array}{l}\text { Celkem } \\
\text { prošlo }\end{array}$ & $\begin{array}{l}\text { Celkem } \\
\text { zastavilo }\end{array}$ & $\begin{array}{l}\text { Podíl prošli-navštívili } \\
(\%)\end{array}$ & $\begin{array}{l}\text { Průměrná délka } \\
\text { zastavení (minuty) }\end{array}$ \\
\hline & 55 & 50 & 91 & 4,29 \\
\hline
\end{tabular}


Tabulka 11: Počet osob zaznamenaných u panelu č. 7 NS Sedmihorky

\begin{tabular}{|l|l|l|l|l|}
\hline $\begin{array}{l}\text { Sedmihorky } \\
\text { Panel č.7 }\end{array}$ & Počet osob & Ženy & Muži & $\begin{array}{l}\text { Nezastavilo } \\
\text { osob }\end{array}$ \\
\hline 6. 6.2009 & 138 & 60 & 75 & 3 \\
\hline 14. 11.2009 & 102 & 41 & 57 & 4 \\
\hline
\end{tabular}

Testy byly vybrány celkem od 50 respondentů, z toho 27 mužů, 23 žen. Průměrný bodový zisk na návštěvníka byl 6,02 bodů z možných osmi. Věkový průměr návštěvníků stezky byl 22,58. Pět respondentů mělo vysokoškolské vzdělání.

Tabulka 12: Průměrný bodový zisk respondentů a přehled zkoumaných vlastností respondentů NS Sedmihorky

\begin{tabular}{|l|l|l|l|l|l|l|l|l|l|}
\hline Sedmihorky & $\begin{array}{l}\text { Počet } \\
\text { osob }\end{array}$ & Muži & Ženy & $\begin{array}{l}\text { Průměrný } \\
\text { bodový } \\
\text { zisk stezky }\end{array}$ & $\begin{array}{l}\text { Průměr } \\
\text { muži }\end{array}$ & $\begin{array}{l}\text { Průměr } \\
\text { ženy }\end{array}$ & $\begin{array}{l}\text { Počet } \\
\text { VŠ }\end{array}$ & $\begin{array}{l}\text { Průměrný } \\
\text { bodový } \\
\text { zisk VŠ }\end{array}$ & $\begin{array}{l}\text { Průměrný } \\
\text { věk } \\
\text { respondentů }\end{array}$ \\
\hline 50 & 23 & 27 & 6,02 & 5,22 & 6,96 & 5 & 7,4 & 22,58 \\
\hline
\end{tabular}

\section{Komparativní analýza}

$\checkmark$ rámci statistické analýzy byly porovnávány vždy dvě dvojice stezek $s$ přibližně srovnatelnými parametry, jedna prožitková, jedna tradiční:

- Jizerka (tradiční) - Oldřichovské háje a skály (prožitková)

- Jedlový důl (tradiční) - Lesní naučná stezka Sedmihorky (prožitková).

Analyzovány byly následující proměnné:

- Poměr návštěvníků, kteří se zastavili, respektive nezastavili na sledovaném stanovišti.

- Doba strávená na stanovišti.

- Znalosti odpovídající dosavadním zastavením naučné stezky zjištěné jednoduchým posttestem. 
Tabulka 13: Srovnání četnosti zastavení na sledovaných stanovištích prožitkových a tradičních naučných stezek

\begin{tabular}{|l|l|l|l|l|}
\hline & Zastavili & Nezastavili & $P$ & X2 \\
\hline Jizerka & 27 & 9 & 0,75 & 0,09 \\
\hline Oldřichov & 32 & 9 & 0,1 & 2,69 \\
\hline Jedlový důl & 41 & 8 & & \\
\hline Sedmihorky & 50 & 5 & 0 & \\
\hline
\end{tabular}

$\mathrm{P}=$ pravděpodobnost náhodného vzniku rozdílů mezi skupinami, $\mathrm{x} 2=$ hodnota chí kvadrátu. Údaje neuvádějí počty návštěvníků, ale jednotek.

Z výsledků nevyplývá, že by se návštěvníci zastavovali častěji u některého z typů stezek $(a=0,05)$. Většina návštěvníků se u stanoviště zastaví a alespoň krátce si jej prohlédne.

Tabulka 14: Srovnání délky zastavení na sledovaném stanovišti prožitkových a tradičních naučných stezek

\begin{tabular}{|l|l|l|l|l|}
\hline & $\begin{array}{l}\text { Počet } \\
\text { jednotek }\end{array}$ & $\begin{array}{l}\text { Čas (min, } \\
\text { sekundy) }\end{array}$ & $\mathrm{P}$ & $\mathrm{t}$ \\
\hline Jizerka & 36 & 3,28 & \multirow{2}{*}{0,0325} & 2,1782 \\
\hline Oldřichov & 41 & 4,93 & & \multirow{2}{*}{0,0001} \\
\hline Jedlový důl & 49 & 2,35 & 4,4684 \\
\hline Sedmihorky & 55 & 4,29 & & \\
\hline
\end{tabular}

Čas = průměrný čas trávený jednotkou $\mathrm{u}$ vybraného panelu $\mathrm{v}$ minutách a sekundách, $\mathrm{P}=$ pravděpodobnost náhodného vzniku rozdílů mezi skupinami, $\mathrm{t}=$ hodnota t-testu

V rámci sledovaných dvojic Ize říct, že na obou prožitkových stezkách strávili návštěvníci vice času, než na srovnatelných tradičních naučných stezkách. 
Tabulka 15: Porovnávání bodových zisků z vědomostního testu

\begin{tabular}{|l|l|l|l|l|l|l|}
\hline & $\begin{array}{l}\text { Počet } \\
\text { respondentů }\end{array}$ & Muži & Ženy & $\begin{array}{l}\text { Průměrný } \\
\text { bodový zisk }\end{array}$ & W & P \\
\hline Jizerka & 50 & 27 & 23 & 4,82 & 2319 & $<=0.16$ \\
\hline Oldřichov & 50 & 23 & 27 & 5,46 & 2486.5 & $<=0.79$ \\
\hline Jedlový důl & 50 & 19 & 31 & 6 & & \\
\hline Sedmihorky & 50 & 27 & 23 & 6,02 & \\
\hline
\end{tabular}

$\mathrm{W}=$ hodnota Wilcoxonova testu, $\mathrm{P}=$ pravděpodobnost náhodného vzniku rozdílů mezi skupinami

Je zjevné, že rozdíly $v$ bodovém hodnocení vědomostního testu mezi sledovanými páry stezek nejsou statisticky významné. Návštěvníci prožitkových stezek dosahují srovnatelných vědomostních výsledků jako návštěvníci tradičních stezek.

Rozdíly mezi chováním respondentů a jejich znalostmi mohly být ovlivněny i dalšími proměnnými. Významným faktorem je věk návštěvníka. Korelační analýza potvrdila, že čím je návštěvník starší, tím vyššího bodového zisku dosahuje. Sílu korelace je možné hodnotit jako střední u všech stezek s výjimkou Sedmihorek.

Tabulka 16: Porovnávání korelace mezi věkem a bodovým ziskem respondenta

\begin{tabular}{|l|l|l|l|l|}
\hline & Věk & Body & P & R \\
\hline Jizerka & 30,28 & 266 & $<0.001$ & 0.58 \\
\hline Oldřichov & 27,66 & 281 & 0.02 & 0.33 \\
\hline Jedlový důl & 31,18 & 277 & $<0.001$ & 0.52 \\
\hline Sedminorky & 22,58 & 301 & 0.35 & 0.13 \\
\hline
\end{tabular}

$\mathrm{R}=$ hodnota korelace podle Spearmanova testu, $\mathrm{P}=$ pravděpodobnost náhodného vzniku rozdílů při oboustranném testu.

Druhým sledovaným znakem bylo pohlaví návštěvníků. Statisticky významný rozdíl přineslo porovnání bodových výsledků mezi muži a ženami pouze na NS Sedmihorky ( $M$ ženy $=6,96, M$ muži $=5,22, W=523, p=0,001$ ), hodnoceno pomocí Wilcoxonova nepárového testu.

Dalším možným faktorem, který mohl ovlivnit respondentův bodový zisk, bylo dosažené vzdělání. Respondenti s vysokoškolským titulem by teoreticky měli dosáhnout ve znalostních dotaznících lepších výsledků než návštěvníci bez vysokoškolského vzdělání.

Tento předpoklad se potvrdil pouze na NS Jedlový důl $(p<0,003)$ při hodnocení Wilcoxonovým nepárovým testem. Je ale třeba upozornit na velmi nevyrovnaný počet 
vysokoškolských a nevysokoškolských respondentů, který validitu porovnání významně zpochybňuje.

\section{Diskuse}

Provedená analýza ukázala, že ze sledovaných párů naučných stezek dokážou prožitkové stezky přitáhnout na delší dobu pozornost návštěvníka, než stezky tradičního typu. Oba typy stezek pak zhruba stejně často motivují návštěvníka k zastavení a z obou si odnáší zhruba stejné množství znalostí. Prožitkové naučné stezky jsou přitom pozorovatelkou hodnoceny jako atraktivnější, tradičním je vytýkáno př́liš velké množství informací a zbytečně odborná terminologie.

Zatímco vyšší míra atraktivity prožitkových stezek není překvapující, je třeba se zastavit u možných př́čin toho, proč nebyl u prožitkových stezek naměřen větší vliv na znalosti návštěvníků, než u stezek tradičních. Nabízejí se tři možná vysvětlení: chyba $\mathrm{v}$ teorii, chyba $v$ implementaci teorie a chyba $v$ měření.

Chybu v teorii nelze na základě provedeného výzkumu vyvrátit ani potvrdit. Nebylo cílem provést zobecnitelný výzkum, který by rozhodl o vyšší efektivitě jednoho typu stezek nad druhým a je otázkou, zda vzhledem k různosti stezek a malému počtu stezek prožitkového typu je takový výzkum vůbec možný. Výsledky, striktně vzato, nevypovídají o ničem jiném, než jsou sledované čtyři naučné stezky.

Ze související teorie Ize vyčíst, že učení prožitkem může být efektivnější než tradiční učení, protože umožňuje zapojit více smyslů a tak lépe aktivizovat mozek (Kovalik \& Olsen, 1994). Zapojení prožitku a jeho reflexe dává př́ležitost aktivizovat rưzné styly učení a tak zapojit širší segment návštěvníků (Kolb, 1984). Vyšší motivační funkci prožitkového učení doložily i výsledky prezentovaného šetření. Zapojení prožitku rovněž koresponduje s doporučeními pro programy environmentální interpretace (Beck \& Cabel, 2002; Ham, 1992).

Možným vysvětlením proto je, že teorie prožitkové pedagogiky není na sledovaných stezkách správně implementována. Obě prožitkové stezky nabízejí jednoduché znalostně zaměřené aktivity a aktivity na formování environmentální senzitivity. Vzhledem k tomu, že test sledoval pouze znalosti návštěvníků, je možné, že znalostně orientované aktivity na prožitkových stezkách neplní správně svoji funkci. Je možné, že se nabízené aktivity př́liš zaměřují na opakování jednoduchých faktografických znalostí a málo motivují k samostatnému zkoumání a prožívání lokality.

Podle dalšího vysvětlení můžeme předpokládat chybu ve vstupní rozvaze o cílech naučné stezky. Naučné stezky u nás tradičně nejsou chápány jako program environmentální interpretace ve smyslu definice programu jako souboru aktivit naplňujícím společné cíle (Newcomer, Hatry \& Wholey, 2004), ale jako prostředku nespecifikovaného výchovně vzdělávacího působení na návštěvníka. Je proto možné, že naučné stezky trpí určitou neujasněností svých cílů a v důsledku nedostatečně integrují programové prostředky potřebné pro jejich dosažení. Chápání naučných stezek jako samostatných programů by mohlo přispět k jejich vyšší efektivitě. Zdá se také, že sledované stezky neodpovídají ani dalším z doporučení Kočí a Mrázové (2009). Stezky nemají jasně vymezený tematický rámec a spojující příběh. Nejsou také průběžně evaluovány.

V neposlední řadě je třeba upozornit na limity výzkumu, které mohou být posledním vysvětlením relativního neúspěchu prožitkových stezek. Výzkum nesledoval řadu proměnných, které prožitkové stezky mohou efektivně ovlivňovat - od zmíněné environmentální senzitivity přes vztah ke konkrétnímu místu či postoje ve vztahu $\mathrm{k}$ výletům do přírody. Je možné předpokládat, že právě $v$ těchto oblastech může spočívat největší význam prožitkových stezek. Pro ověření této domněnky by bylo třeba provést 
další výzkumná šetření, pravděpodobně založená na kvalitativní metodice. Porovnávané stezky nebyly zcela srovnatelné a výsledky mohly být ovlivněny jinými faktory. Vliv na frekvenci a délku zastavení mohla mít i prítomnost pozorovatelky (byt́ umístěné v odstupu od stanoviště a zadávající otázky až ve chvíli, kdy jednotka stanoviště opouštěla).

Výsledky proto nelze přeceňovat ani zobecňovat. Vzhledem $\mathrm{k}$ nedostatku relevantních výzkumů jej nicméně chápeme jako jeden z prvních příspěvků k diskusi o environmentální interpretaci, její efektivitě a metodice u nás. Předpokládáme, že na téma je možné navázat řadou souvisejících evaluačních výzkumů, z jejichž metaanalýzy pak mohou vyplynout důležitá doporučení pro teorii i praxi.

\section{Použitá literatura}

- Amann, M. (2003). Pojd'me na to od lesa. Príručka ekologické výchovy a lesní pedagogiky. Vimperk: Správa národních parků a CHKO ve Vimperku.

- Back, L., \& Cable, T. (2002). Interpretation for the 21st century. Champaign.

- $\quad$ http://www.kentdowns.org.uk/ (2004). . Retrieved from http://www.kentdowns.org.uk

- HAM Sam H, (1992). Environmental interpretation : A practical guide for people with big ideas and small budgets. Colorado: Fulcrum Publishing.

- Hendl, J. (2004). Přehled statistických metod zpracování dat. Praha: Portál.

- Hendl, J. (2008). Kvalitativní výzkum. Základní teorie, metody a aplikace. Praha: Portál.

- HUNGERFORD Harold R, , \& VOLK Trudi L, (1990). Changing Learner Behavior Through Environmental Education. The Journal of Environmental Education. The Journal of Environmental Education, 21(3), 8-21. Retrieved from http://www.tandfonline.com/doi/abs/10.1080/00958964.1990.10753743 http://dx.doi.org/10.1080/00958964.1990.10753743

- Knapp, D. (1996) Evaluating The Impact Of Environmental Interpretation : A Review of Three Studies. In Coalition for Education in the Outdoors Research Symposium Proceedings. ]s.I.] : ]s.n (pp. 127-135). .

- Knapp, D. (1997). Environmental Education and Environmental Interpretation: The Relationships. : National Association for Interpretation.

- Knapp, D., Volk, T. L., \& Hungerford, H. R. (1997). The identification of empirically derived goals for program development in environmental interpretation. The Journal of Environmental Education. 1997, 28(3), 24-34.

- Naučné stezky (2003). . Retrieved from http://www.kvetenacr.cz/naucstezky.asp

- Kolb, D. (1984). Experience as the source of learning and development. Prentice Hall: Upper Sadle River.

- Kovalik, S. J., \& Olsen, K. D. (1994). Kid's eye view of science. A Teacher's Handbook for Implementing an Integrated Thematic Approach to Teaching Science, $K-6$. Kent: Center for the Future of Public Education.

- Mrázová, L., \& Kočí, K. (2009). Tvorba naučných stezek : Metodická př́ručka pro seminár pořádaný Českým Švýcarskem o.p.s. Krásná lípa: s.n.

- Newcomer, K. E., Wholey, J. S., \& Hatry, H. P. (2004) Meeting the Need for Practical Evaluation Approaches: An Introduction. In Handbook of Practical Program Evaluation. San Francisco: Jossey-Bass. 
- Patton, M. Q. (2002). Qualitative Research and Evaluation Methods. California: Sage Publications.

- Warner, A. (2009). Creating Earth Adventures : Self-Guided Programs To Connect Children With Nature. Green Teacher, 85, 3-8.

\section{Př́lohy}

\section{Jizerka}

1. Jaký je původní ráz zdejší krajiny? A pralesy B pralouka C lesy

2. Z jaké horniny je vyvřelý masiv Bukovec? A z čediče B ze žuly C z pískovce

3. Jak se jmenuje potok protékající osadou Jizerka?.

4. Napište prosím, jaké 2 druhy květin jsou typický pro zdejší oblast?

1 . 2.

5. Napište, které 2 druhy ptáků se zde vyskytují?

1. 2

6. Jakou rostlinu má CHKO Jizerské hory ve znaku? A suchopýr B pampeliška C úpolín

Po kolikáté procházíte místní naučnou stezkou? A poprvé B 1-2 C 2 a více

Věk... Pohlaví muž - žena

Dosažené vzdělání.

J Děkuji za vyplnění a přeji krásný den J

\section{Jedlový důl}

1. Jaké jsou původní lesy zdejší oblasti? A jehličnaté B smišené C listnaté

2. Který strom je charakteristický pro Jedlový důl? A modř́n B bríza C jedle

3. Jak se jmenuje potok protékající Jedlovým dolem?

4. Napište prosím, jaké 2 druhy květin jsou typické pro zdejší oblast?

5. 1 2

6. Napište, které 2 druhy ptáků se zde vyskytují?

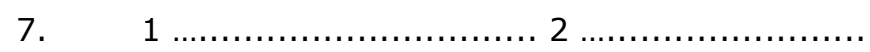

8. Jakou rostlinu má CHKO Jizerské hory ve znaku? A suchopýr B pampeliška C úpolín 
9. Po kolikáté procházíte místní naučnou stezkou? A poprvé B 1-2 C 2 a více

10. Věk .... Pohlaví muž -žena

11. Dosažené vzdělání.

12. J Děkuji za vyplnění a přeji krásný den J

\section{Oldřrichovské háje a skály}

1. Který strom je typický pro Oldřichovské háje? A smrk stř́ibrný B buk lesní C javor klen

2. Co je oplocenka? A lesní oplocená chata B druh housenky C uměle vytvořená ochrana stromů před škůdci

3. Kolika let se dožívá buk lesní? A 70let B 150let C více než 250let

4. Napište prosím, jaké 2 druhy květin jsou typický pro zdejší oblast?

1. 2 .

5. Napište, které 2 druhy ptáků se zde vyskytují?

1. 2 .

6. Co za symbol má organizace Suchopýr, která pomohla vytvořit zdejší naučnou stezku, ve znaku? A rostlinu B zviŕre C hory

Po kolikáté procházíte místní naučnou stezkou? A poprvé B 1-2 C 2 a více

Věk....... Pohlaví muž - žena

Dosažené vzdělání.

J Děkuji za vyplnění a přeji krásný den J

\section{Lesní naučná stezka Sedmihorky}

1. Který strom je typický pro Hruboskalsko? A borovice B bříza C jedle bělokorá

2. Co je oplocenka? A lesní oplocená chata B druh housenky C uměle vytvořená ochrana stromü před škůdci

3. Až kolika metrů dorůstá přeslička? A 15. metrů B 5. metrů C 2. metrů

4. Napište prosím, jaké 2 druhy listnatých stromů se vyskytují ve zdejší oblasti?

1. 2

5. Napište, které 2 druhy ptáků se zde vyskytují? 
1. 2.

6. Co za symbol má zdejší středisko ekologické výchovy, které pomohla vytvořit zdejší naučnou stezku, ve znaku ? A rostlinu B zviřre C hory

Po kolikáté procházíte místní naučnou stezkou? A poprvé B 1-2 C 2 a více

Věk ....... Pohlaví muž - žena

Dosažené vzdělání.

J Děkuji za vyplnění a přeji krásný den J 
Časopis Envigogika vydává Centrum pro otázky životního prostředí UK. Vývoj časopisu je podpořen projektem OP VK Mezioborová sít udržitelného rozvoje.

Více najdete na internetových stránkách projektu mosur.czp.cuni.cz
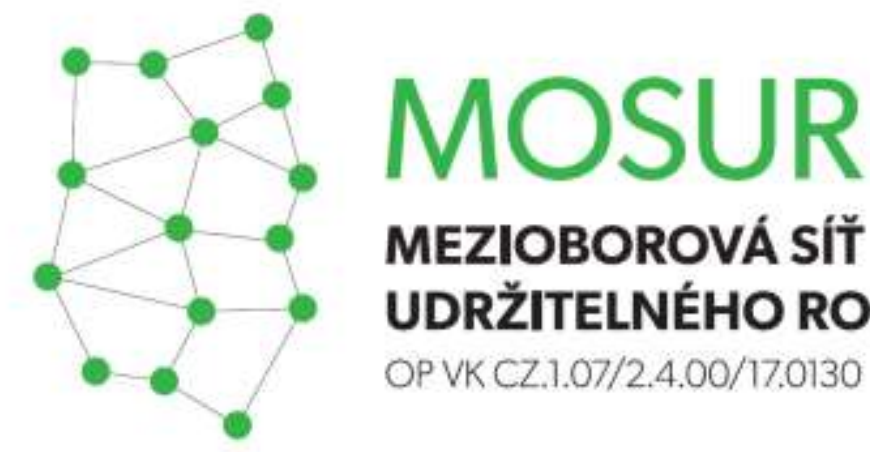

MEZIOBOROVÁ SÍT̆ UDRŽITELNÉHO ROZVOJE

OP VK CZ.1.07/2.4.00/17.0130

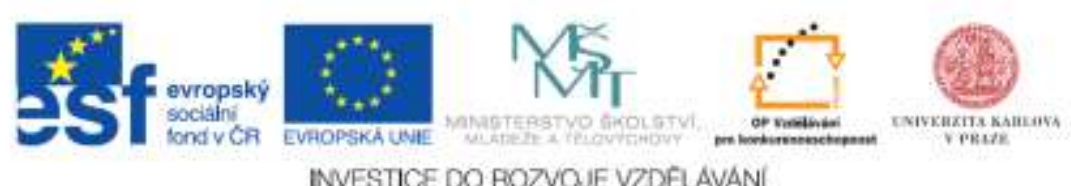

INVESTICE DO ROZVOUE VZDELAVANI 